\title{
Sequence of species selection by cattle and sheep on South African sourveld
}

\author{
PETER J. O’REAGAIN AND ERIC A. GRAU
}

\begin{abstract}
Authors are principal scientist, Grazing Land Management Unit, Department of Primary Industries, P.O. Box 976, Charters Towers, $Q 4820$, Australia, and lecturer, Department of Statistics and Biometry, University of Natal, P.O. Box 375, Pietermaritzburg 3200, South Africa. At the time of the research the senior author was principal agricultural scientist, Döhne Agricultural Development Institute, Private Bag X15, Stutterheim 4930, South Africa
\end{abstract}

\begin{abstract}
The sequence of species selection over the grazing period directly determines the effectiveness of different grazing systems. Knowledge of this sequence is also important in understanding the plant-animal interface. The sequence of tiller defoliation by cattle and sheep was compared for 7 range grasses at $\mathbf{4}$ different sites in South African sourveld. Defoliation frequency and height was monitored daily over a 6-day grazing period at each site.

The sequence of species selection was the same for cattle and sheep although the acceptability of some grasses varied between animal species. Preferred species were always grazed first along with some $(<20 \%)$ utilization of species of intermediate acceptability. When about $60 \%$ of the tillers of the preferred species had been defoliated, regrazing of these tillers commenced and the rate of utilization of intermediate species increased. Only after 80 to $100 \%$ of the tillers of preferred and intermediate species had been defoliated were tillers of the least-preferred species grazed. Sheep were more selective and tended to graze the least-preferred species later in the grazing period than did cattle. There was no difference between cattle and sheep in the frequency of tiller defoliation over the grazing period but tillers were defoliated to a lower height $(P<0.01)$ and more tissue removed $(P<0.01)$ under sheep grazing. Cattle and sheep are therefore likely to differ in their potential impact upon rangeland.
\end{abstract}

Key Words: defoliation frequency, defoliation height, grazing management

Animals on rangeland commonly encounter a diversity of plant species of widely varying acceptability. Although the factors which determine why species are selected have frequently been investigated, relatively little is known about how species are selected, particularly under conditions of changing forage avail-

The authors thank T.G. O'Connor and 2 anonymous referees for comments on an earlier draft, B.C. Goetsch for technical assistance and M.G. McMaster for assistance in manuscript preparation.

Manuscript accepted 11 Nov. 1994. ability. This is of particular importance under rotational grazing where the relative availability of different plant species changes rapidly over the period of occupation in a paddock. Animals are thus confronted with a series of foraging decisions about when to stop rejecting and start consuming species of lower acceptability when encountered. This is manifested as a sequence of species selection over the grazing period as animals progressively include species of lower and lower acceptability in their diet.

Knowledge of this sequence is necessary to determine the effectiveness of different grazing systems and to predict their potential impact on rangeland. Many currently recommended grazing systems assume patterns of species selection which are largely untested (O'Reagain and Turner 1992). Such systems may, therefore, be incapable of achieving stated objectives, possibly resulting in range degradation.

The sequence of species selection over the grazing period has been investigated for cattle (Daines 1980; Danckwerts et al. 1983; O'Reagain and Mentis 1989) and for cattle and sheep grazing together (Stoltsz and Danckwerts 1990). Generally, preferred species, and to a lesser extent, those of intermediate acceptability are grazed first, but less-preferred (avoided) species are only consumed after the more-preferred species in the sward have been extensively regrazed. The extent to which this sequence applies to sheep is, however, unknown and warrants investigation. The primary objective of this study was to compare the sequence of species selection by cattle and sheep over the grazing period.

The frequency and intensity of tiller defoliation is also important as it directly affects plant growth and survival. Sheep are considered to be particularly detrimental to rangeland as they reputedly defoliate tillers more frequently and severely than do cattle (O'Reagain and Turner 1992). However, while this aspect has been investigated separately for cattle (e.g. Gammon and Roberts 1978b; Gillen et al. 1990) and sheep (e.g. Hodgson 1966; Hodgson and Ollerenshaw 1969) no direct cattle-sheep comparison appears to exist. The assertion that sheep defoliate tillers more frequently and severely than cattle is therefore untested.

The second objective of the study was to test the hypotheses that, (i) the frequency and (ii) the severity of tiller defoliation are greater under sheep than under cattle grazing. These hypotheses 
were rejected if a significant $(P \leq 0.05)$ difference was not detected between the 2 animal species.

\section{Procedure}

\section{Study Area}

The experiment was conducted at the Döhne Agricultural Development Institute $\left(32^{\circ} 31^{\prime} \mathrm{S}, 27^{\circ} 28^{\prime} \mathrm{E}\right.$; elevation $\left.899 \mathrm{~m}\right)$ near Stutterheim, South Africa. Mean annual rainfall is $752 \mathrm{~mm}$ (40year mean), falling mainly in summer (October-March). Mean maximum and minium air temperatures are 25 and $14^{\circ} \mathrm{C}$ respectively in summer, and 18 and $7^{\circ} \mathrm{C}$ respectively in winter. The vegetation is an open grassland termed the Döhne Sourveld (Acocks 1988) and consists of a dense, perennial grass community of medium height. Forbs are generally rare or absent.

\section{Experimental Design}

Four different rangeland sites, varying widely in species composition, were used in the investigation (Table 1). These were an area dominated by Eragrostis plana Nees (eragrostis site), an area dominated by Tristachya leucothrix Nees (tristachya site), an area dominated by Themeda triandra Forsk and $T$. leucothrix (themeda site), and a secondary grassland community dominated by Hyparrhenia hirta (L.) Stapf (hyparrhenia site). Nomenclature follows Gibbs Russell et al. 1990. All sites were burnt in September 1990 to remove residual herbage and divided into 6 blocks measuring $24 \times 50 \mathrm{~m}$. Thereafter, blocks were grazed periodically by cattle and sheep as part of another research program, reported elsewhere (O'Reagain 1994).

In January 1992, two blocks of similar height and species composition were selected at each of the 4 sites. At each site 1 block was grazed by cattle and the other by sheep. Blocks were stocked with 18 Döhne Merino wethers (mean mass $35 \mathrm{~kg}$ ) or 3 Bonsmara steers (mean mass $400 \mathrm{~kg}$ ). It was assumed that 6 sheep provide a similar stocking pressure in terms of metabolic mass (mass ${ }^{0.75}$ ), to 1 steer (Meissner 1982).

Blocks were grazed for 6 consecutive days ( 5 for the hyparrhenia site) from 0630 hours on Monday (day 1) to 1500 on Saturday (day 6). Grazing began on 3 February (tristachya site), 24 February (eragrostis site), 16 March (hyparrhenia site) and 30 March (themeda site) 1992. An attempt was made to simulate a period of occupation in a rotational grazing system as this is the recommended form of grazing management in South Africa (O'Reagain and Turner 1992). When the present trial was conducted, no signs of previous grazing were evident.

All animals were sourveld raised and familiar with the grasses investigated. Animals were supplemented with a salt-phosphate lick as is common practice in the area. Between experimental periods, animals grazed together on veld similar to the study areas.

\section{Plant Measurements}

At each site, 3 tussock grasses were selected, which, on the basis of earlier work (O'Reagain and Mentis 1989; Stoltsz and Danckwerts 1990; O'Reagain 1992) were taken to represent preferred, less-preferred and avoided species in terms of the preference exhibited for them by cattle and sheep. In order of decreasing preference, species chosen were Andropogon appendiculatus
Nees, T. leucothrix and Alloteropsis semialata subsp. eckloniana (Nees) Gibbs Russell (tristachya site), A. appendiculatus, $T$. triandra and E. plana (eragrostis site), T. triandra, T. leucothrix and $A$. semialata (themeda site), and $H$. hirta, Heteropogon contortus (L.) Roem and Schult and E. plana (hyparrhenia site).

In each block, a single transect was laid out for each of the 3 species, with 25 tussocks of the species located at regular intervals along the transect. Transects ran parallel to each other, about $2 \mathrm{~m}$ apart. Due to the small paddock (block) size, it was assumed that the frequency and intensity of tiller defoliation would be independent of transect location.

Tussocks were identified using numbered, colour-coded, wire tags inserted into bare ground about $10 \mathrm{~cm}$ from each tussock. In each, 1 intact, vegetative, green tiller was selected and tagged at its base with a plastic-coated wire ring. This gave a total of 25 marked tillers for each of the 3 species in each block. Tillers were chosen at random from all possible locations within a tussock and varied in height within a species.

Immediately before grazing, the extended height of the tallest leaf of each marked tiller was measured. Tillers were thereafter inspected daily at 1400 hours and the presence and height of any defoliation recorded. The grazed tips of defoliated tillers were marked with typist's correcting fluid to distinguish subsequent defoliations. Correcting fluid does not appear to effect subsequent tiller selection (Gammon and Roberts 1978a; Danckwerts et al. 1983). On each day, and at the end of the grazing period, the total number of tillers which had been defoliated once, twice, three times or which were undefoliated, was computed for each species. The percentage (\%) of tiller removed was calculated according to the formula:

$\%$ Tiller removed $=($ Initial tiller height-Final defoliation height/Initial tiller height) $\times 100$.

The few tillers which were only partially defoliated, i.e. only 1 leaf grazed, were not included in this calculation. All defoliations could be directly attributed to experimental animals as indigenous ungulates were absent.

\section{Statistical Analysis}

The study was not replicated per se as it was considered more important to repeat the experiment at sites of different species composition rather than to repeat it a number of times under identical conditions. Data for each site were analyzed separately. The sequence (order) of species selection by cattle and sheep, was analyzed using logistic regression (GENSTAT 1984). As tillers were either grazed or ungrazed, data were binomially distributed necessitating the using of the logit link function (Sokal and Rohlf 1981; p. 764) which provides the log-odds that a subject will have a characteristic relative to any other characteristic.

The model was based on the total number of tillers of each species defoliated on each day of a grazing period. The general form of the model is: $\operatorname{logit}\left(\pi_{\mathrm{i})}=\alpha+\sum \mathrm{B}_{\mathrm{i}} \mathrm{x}_{\mathrm{ij}}\right.$ where logit $\left(\pi_{\mathrm{i}}\right)$ is the logit link function, given as In $\left(\pi_{\mathrm{i}} /-\pi_{\mathrm{i}}\right)$. Equivalently,

$$
\pi_{\mathrm{i}}=\exp \left(\alpha+\sum \mathrm{B}_{\mathrm{j}} \mathrm{x}_{\mathrm{ij}}\right) / 1+\exp \left(\alpha+\sum \mathrm{B}_{\mathrm{j}} \mathrm{x}_{\mathrm{ji}}\right)
$$

where $\pi_{\mathrm{i}}$ is the probability that the ${ }_{\mathrm{i}}$ th tiller will be defoliated, $\alpha$ is a constant, $x_{j i}$ is the set of ${ }_{j}$ explanatory variables used to predict the logit of $\pi_{i}$ and $B_{j}$ are the coefficients of these variables (Pagnano and Gauvreau 1993).

The following explanatory variables were included in the mod- 
els. 'Day' refers to the probability that any tiller will be defoliated with time and measures the degree of utilization through the grazing period. A significant, positive coefficient indicates that the probability of defoliation increases with time. 'Animal' refers to animal type, i.e. cattle or sheep. Sheep were chosen as the baseline so a significant positive coefficient for this variable indicates that cattle are more likely to defoliate tillers than sheep. Conversely, a negative coefficient indicates that sheep are more likley to defoliate tillers than cattle. 'Grass species' gives the probability that a particular grass will be defoliated relative to the baseline species at that site. Baseline species were $T$. triandra (themeda and eragrostis sites), $H$. hirta (hyparrhenia site) and $T$. leucothrix (tristachya site). A significant positive coefficient indicates that the species is more likely to be defoliated relative to the baseline species while a negative coefficient indicates the reverse.

The 'day $x$ animal' interaction accounts for differences in the probability of tiller defoliation over time by cattle and sheep. As sheep are the baseline, a significant, positive coefficient here indicates that tillers are more likely to be defoliated by cattle later in the grazing period than by sheep. 'Animal $\times$ grass' gives the probability that a particular species will be defoliated by cattle relative to defoliation of the baseline species by sheep. Here, a significant positive coefficient indicates that cattle are more likely than sheep to defoliate a grass in preference to the baseline
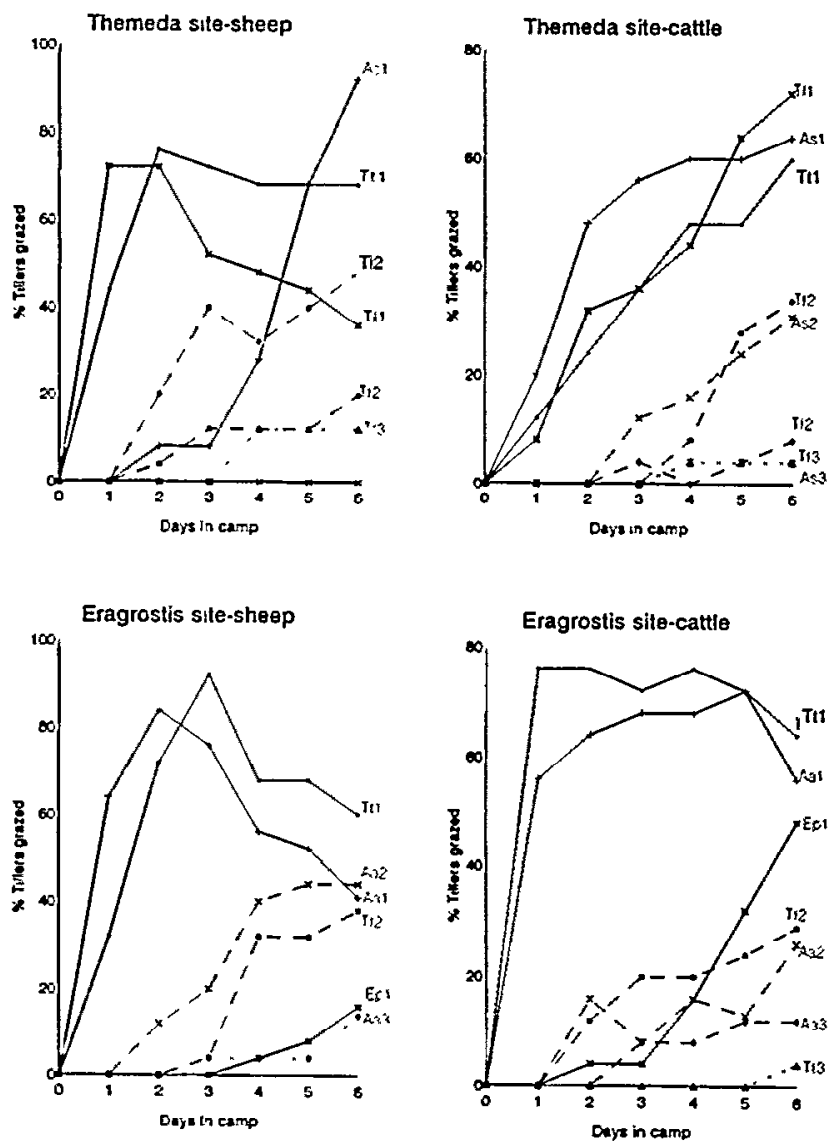

Fig. 1a. Percentage of tillers grazed once (solid line), twice (dashed line) or 3 times (dotted line) over a 6-day grazing period by cattle and sheep at the themeda and eragrostis sites $(\mathrm{Aa}=\mathrm{A}$. appendiculatus, $\mathrm{As}=A$. semialata, $\mathrm{Ep}=E$. plana, $\mathrm{Hc}=H$. contortus, $\mathrm{Hh}=H$. hirta, $\mathrm{Tl}=T$. leucothrix, $\mathrm{T} \mathrm{t}=T$. triandra . species while the reverse applies for a negative coefficient. Significance of model coefficients are based on Student's t-test.

Overall goodness of fit of the model is based on an analysis of deviance, where the residual deviance is a measure of the variation in the response not explained by the model. The residual deviance has an approximate chi-squared distribution with degrees of freedom corresponding to the residual degrees of freedom. If the residual deviance is not significant, the model is a good fit.

The total frequency of tiller defoliations, i.e. the number of tillers defoliated 1,2, or 3 times, for each grass species over the grazing period under cattle and sheep grazing was analyzed using loglinear analysis (SAS 1991) which primarily tests for the presence of interactions in the data (Sokal and Rohlf 1981). Grass species and animal type were used as 'state' (independent) variables while the number of tillers in each defoliation class, were used as 'fate' (dependent) variables (Caswell 1989 p. 34). The null hypothesis tested was that the frequency of tiller defoliation at each site was independent of grass species or animal type.

Due to the relatively small sample sizes the possibility existed of significant cattle-sheep differences being obscured in the general loglinear analyses. The log-likelihood ratio or $\mathrm{G}^{2}$-test (Sokal and Rohlf 1981) was therefore used to compare the frequency of tiller defoliation (1) for individual grasses under cattle and sheep
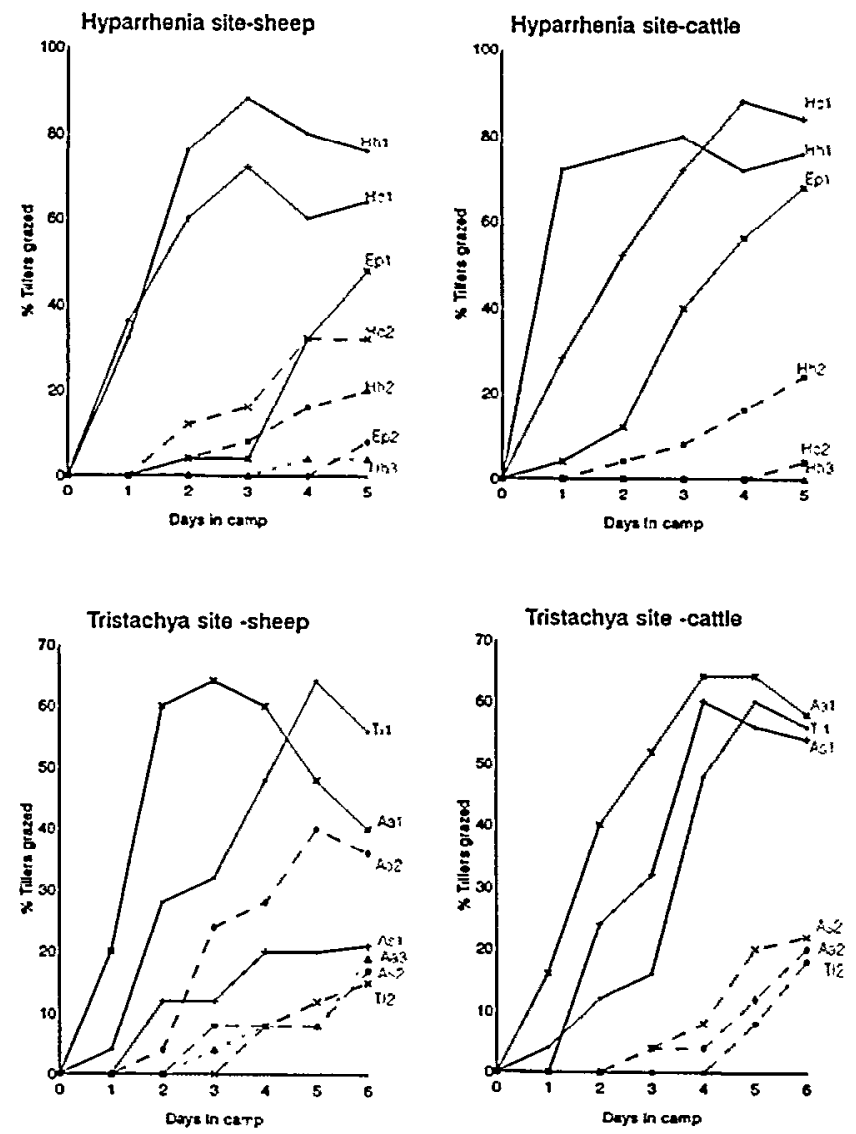

Fig. 1b. Percentage of tillers grazed once (solid line), twice (dashed line) or 3 times (dotted line) over a 6-day grazing period by cattle and sheep at the hyparrhenia and tristachya sites. Species codes as for Fig. 1a. 
Table 1. Proportional species compositions of the eragrostis (Erag), tristachya (Tris), themeda (Them) and hyparrhenia (Hypr) sites in the Döhne sourveld, South Africa.

\begin{tabular}{lrrrr}
\hline \hline & \multicolumn{4}{c}{ Site } \\
\cline { 2 - 5 } Species & Erag & Tris & Them & Hypr \\
\hline Alloteropsis semialata & 4 & 13 & 6 & \\
Andropogon appendiculatus & 19 & 10 & 12 & \\
Cynodon dactylon & 4 & & & 11 \\
Elionurus muticus & & 1 & 3 & \\
Eragrostis capensis & & & 2 & 2 \\
Eragrostis chloromelas & 6 & & & 2 \\
Eragrostis curvula & 3 & 1 & & 8 \\
Eragrostis plana & 37 & & 5 & 9 \\
Eragrostis racemosa & & & 2 & \\
Harpochloa falx & 3 & 5 & 4 & \\
Heteropogon contortus & 1 & 8 & 3 & 13 \\
Hyparrhenia hina & & & & 46 \\
Microchloa caffra & & 7 & 1 & \\
Sporabolus africanus & 5 & 2 & 6 & 9 \\
Themeda triandra & 15 & 10 & 27 & \\
Tristachya leucothrix & 3 & 43 & 29 & \\
TOTAL & 100 & 100 & 100 & 100 \\
\hline
\end{tabular}

grazing and (2) for different grass species at the same site under cattle and sheep grazing, respectively.

Comparison of the height of tiller defoliation and the percentage of tiller removed under cattle and sheep grazing was based on a factorial design using 'animal' as a treatment and grass species as a factor (GENSTAT 1984). Individual tillers were used as replications and, consequently, the trial is pseudo-replicated (Hurlburt 1981). Where necessary, percentage data were transformed using an angular transformation (Sokal and Rohlf 1981).

\section{Results}

Sequence of Species Selection

At the themeda site, sheep first selected $T$. triandra and $T$. leu-

Table 2. Model $t$-values for variables in the logistic regression of the sequence of species selection by cattle and sheep at 4 sites in the Döhne sourveld. Site codes as for Table 1. (Themeda site: baseline species $=T$. triandra, species $2=A$. semialata, species $3=T$. leucothrix. Eragrostis site: baseline species $=T$. triandra, species $2=A$. appendiculatus species $3=E$. plana. Hyparrhenia site: baseline species $=H$. hirta, species $2=$ $H$. contortus, species $3=E$. plana. Tristachya site: baseline species $=T$. leucothrix, species $2=A$. semialata, species $3=A$. appendiculatus). See text for details.

\begin{tabular}{lcrcc}
\hline \hline & & & \multicolumn{3}{c}{ Site } & \\
\cline { 4 - 6 } Species & Them & Erag & Hypr & Tris \\
\hline Constant & -3.1 & -4.4 & -4.0 & -7.2 \\
Day & 8.2 & 6.1 & 8.1 & 8.3 \\
Animal 'caltle' & -3.3 & 4.2 & 2.6 & -1.7 \\
Grass-species 2 & -8.0 & 3.2 & -1.1 & -5.4 \\
Grass-species 3 & 2.8 & -7.3 & -8.7 & 4.6 \\
Day $\times$ animal & -0.1 & -3.5 & -2.7 & 0.7 \\
Animal $\times$ species -2 & 7.9 & -3.6 & -1.8 & 5.2 \\
Animal $\times$ species-3 & -3.0 & 3.5 & 2.8 & -0.8 \\
Residual deviance & 31.2 & 11.0 & 16.1 & 36.7 \\
\hline
\end{tabular}

$\left[t_{(0.05)} 28 \mathrm{df}=2.048\right]$

$\left[\mathrm{t}_{(001)} 28 \mathrm{df}=2.763\right]$

$\left[x^{2}(0.05) 28 \mathrm{df}=41.33\right]$
Table 3. Probability values for loglinear analysis of the dependence of tiller defoliation (Def.) frequency on grass species, animal species, and an animal-grass species interaction at $\mathbf{4}$ sites in the Döhne sourveld, South Africa. (Site codes as for Table 1).

\begin{tabular}{lcccc}
\hline \hline & & & & \\
\cline { 4 - 6 } Species & Them & Erag & Hypr & Tris \\
\hline Def. $\times$ grass & 0.096 & 0.238 & 0.207 & 0.293 \\
Def. $\times$ animal & 0.008 & 0.389 & 0.062 & 0.141 \\
Def. $\times$ Animal $\times$ grass & 0.004 & 0.677 & 0.183 & 0.293 \\
\hline
\end{tabular}

cothrix, defoliating more than $70 \%$ of these tillers in the first 2 days of grazing (Fig. 1a). Thereafter, many of these tillers were regrazed but $A$. semialata was only really utilized after day 3 when the majority of $T$. triandra and $T$. leucothrix tillers had been defoliated 1 or more times. With cattle, all 3 grass species experienced similar rates of utilisation although $A$. semialata appeared to be the most preferred of the 3 grasses. Regrazing of tillers occurred from day 3 onwards.

Tillers of all species were less likely to be defoliated under cattle than under sheep grazing as indicated by the negative 'animal' term in the logistic model (Table 2). Overall, T. leucothrix was likely to be defoliated in preference to $T$. triandra while the latter grass was likely to be defoliated in preference to $A$. semialata. Despite this, cattle were more likely to choose $A$. semialata, but less likely to choose $T$. leucothrix, over $T$. triandra, than sheep. Sheep selectivity for individual species was also more pronounced than that of cattle. Overall, the logistic model showed a good fit to the data, as it did at all sites, as indicated by the nonsignificance of the residual deviance (Table 2).

At the eragrostis site, both cattle and sheep selected strongly for A. appendiculatus and T. triandra (Fig. 1a) with many of these tillers being subsequently regrazed. Eragrostis plana was largely avoided and only grazed near the end of the 6 day grazing period. The negative 'day $x$ animal' term in the model indicates that sheep were more likely to graze tillers near the end of the grazing period than cattle (Table 2). This indicates that sheep were more likely to resist grazing avoided species such as $E$. plana. There were large differences in preference for different species with $E$. plana having a significantly $(P \leq 0.01)$ lower probability of being grazed than the baseline species, $T$. triandra. Nevertheless, cattle were more likely to choose $E$. plana over $T$, triandra, than were sheep (Table 2).

At the hyparrhenia site sheep first grazed $H$. hirta and $H$. contortus (Fig. 1b). Regrazing of both species then occurred with sheep defoliating $E$. plana tillers last. Cattle also selected strongly for $H$. hirta and, to a lesser extent, for $H$. contortus, but consumed $E$. plana earlier in the grazing period than did sheep. Amongst all grass species, tillers were more likely to be defoliated under cattle than under sheep grazing but, conversely, were more likely to be defoliated near the end of the grazing period by sheep (Table 2). There were big differences in preference for the different grasses, with animals far more likely to graze $H$. hirta and $H$. contortus tillers than those of $E$. plana. However, as before, cattle were more likely to consume $E$. plana than were sheep.

At the tristachya site, sheep first selected A. appendiculatus followed by $T$. leucothrix. Regrazing of $A$. appendiculatus was extensive and more than $60 \%$ of these tillers were grazed 2 or more times over the 6-day grazing period (Fig. 1b). Sheep avoid- 
ed $A$. semialata and grazed only a small proportion of these tillers. Cattle defoliated $A$. appendiculatus tillers in preference to those of $A$. semialata which, in turn, were defoliated in preference to $T$. leucothrix. Despite these differences, the 3 species were defoliated at roughly similar rates, with regrazing of all species occurring in the latter half of the grazing period. Overall, tillers had an almost equal probability of being defoliated under cattle and sheep grazing (Table 2). Differences in preference for species were highly significant $(P \leq 0.01)$ with $A$. semialata and $A$. appendiculatus having a lesser and greater chance respectively, than $T$. leucothrix of being defoliated. Differences between animal types were again marked with cattle being far more likely to choose A. semialata over $T$. leucothrix, than sheep.

For both cattle and sheep, the utilisation of any species was strongly dependent upon the extent of utilisation of the most-preferred species present (Fig. 2). In most cases a 2 stage response was evident. In stage 1 , when the degree of utilisation of the preferred species was relatively low and ungrazed tillers of this species were available. Utilisation of less-preferred species was low, or in the case of avoided species, virtually non-existent. However, as the utilisation of the preferred species increased, a threshold was crossed to stage 2 where utilisation of less preferred or avoided species increased dramatically (Fig. 2). Generally, the greater the difference in preference between the
Themeda site

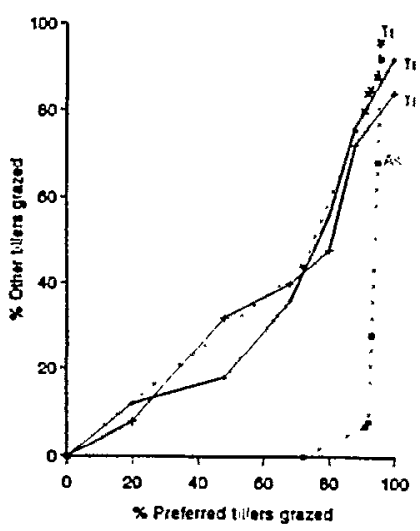

Hypamhenia site

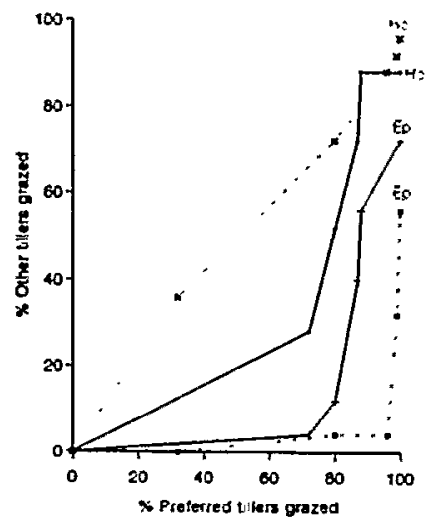

Eragrostis site

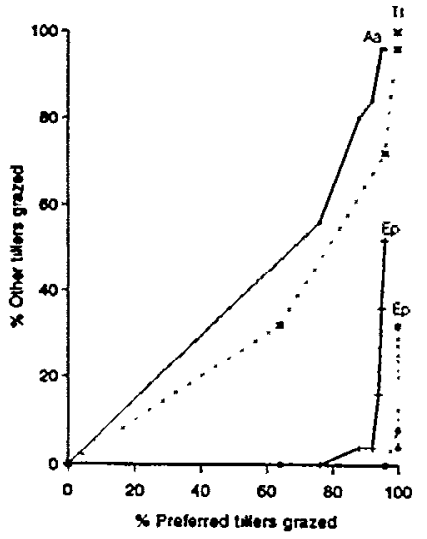

Tristachya site
Fig. 2. The relation between the percentage of tillers of preferred species defoliated and the percentage of tillers of other species grazed by cattle solid line) and sheep broken line) at 4 sites in the Döhne sourveld. Species codes as for Fig. 1a. preferred and the next most preferred species, the higher the threshold and the lower the pre-threshold utilisation of the lesspreferred species. Where 2 species were of a similar preference ranking, utilisation of the 2 species was fairly similar (Fig. 2).

\section{Frequency of Tiller Defoliation}

The majority of tillers at all sites and under both cattle and sheep grazing were defoliated at least once and some cases 2 or 3 times by the end of the grazing period (Fig. 3). Based on the loglinear analysis, the frequency of tiller defoliation was, with the exception of the themeda site, independent of grass species and animal type at all sites (Table 3 ). On an individual grass species basis, the frequency of tiller defoliation was dependent on animal type in 5 out of 12 comparisons. However, the results were inconsistent (Fig. 3) in that in 2 cases the frequency of tiller defoliation was higher under cattle than under sheep grazing, while in the remaining 3 cases the reverse occurred. This inconsistency and the general lack of significance of the overall analysis indicates no real difference between cattle and sheep in the frequency of tiller defoliation.

Under sheep grazing, the frequency of tiller defoliation was strongly dependent on grass species at all sites (Table 4) highlighting the selective nature of these animals. In contrast, under cattle grazing the frequency of tiller defoliation was only dependent upon species at the eragrostis $(P \leq 0.01)$ and hyparrhenia $(P \leq 0.05)$ sites.

Table 4. $\mathbf{G}^{2}$-values for the dependence of tiller defoliation frequency on grass species under cattle and sheep grazing at 4 sites in the Döhne sourveld, South Africa.

\begin{tabular}{llc}
\hline & \multicolumn{2}{c}{ Animal } \\
\cline { 2 - 3 } Site & Sheep & Cattle \\
\hline Themeda & $21.43^{* *}$ & 8.15 \\
Eragrostis & $61.64^{* * *}$ & $24.70^{* * *}$ \\
Hyparrhenia & $21.79^{* * *}$ & $12.64^{*}$ \\
Tristachya & $28.79^{* *}$ & 0.781 \\
\hline
\end{tabular}

*Significant $P \leq 0.05$

**Significant $P \leq 0.01$

*** Significant $P \leq 0.0001$

\section{Severity of Tiller Defoliation}

Sheep defoliated tillers at a significantly $(P \leq 0.05)$ lower height than cattle (Table 5) with this difference being consistent across all sites and all grass species. Mean differences in defoliation height between the 2 animal species ranged from $1 \mathrm{~cm}$ for $T$. triandra (themeda site) to $3.2 \mathrm{~cm}$ for A. appendiculatus (tristachya site).

Differences in the percent of total tiller length removed were also significant $(P \leq 0.05)$ with sheep consistently removing a greater percentage of tiller length than cattle (Table 6). This difference was also consistent across all sites and species and ranged from $0.48 \%$ for $A$. semialata (themeda site) to $16.57 \%$ for $H$. contortus (hyparrhenia site).

\section{Discussion}

The sequence of species selection over the grazing period could be divided into 3 distinct stages. In the first stage, animals selected the most preferred species in the sward with some utilisation 
Table 5. Mean height $(\mathrm{cm})$ of tiller defoliation by cattle and sheep for different grass species at $\mathbf{4}$ sites in the Döhne sourveld. Statistical comparisons are for cattle versus sheep at each site. (Site codes are as for Table 1).

\begin{tabular}{|c|c|c|c|c|}
\hline$\overline{\overline{\text { Site }}}$ & & Species & & Cattle vs sheep \\
\hline & $-\ldots$ & $-(\%)$ & $\ldots-\ldots$ & \\
\hline Them & A. semialata & T. triandra & T. leucothrix & \\
\hline Cattle & 5.70 & 5.28 & 4.27 & ** \\
\hline Sheep & 4.52 & 4.28 & 2.84 & \\
\hline Erag & A. appendiculatus & T. triandra & E. plana & \\
\hline Cattle & 7.26 & 5.03 & 7.50 & ** \\
\hline Sheep & 4.63 & 3.12 & 6.00 & \\
\hline Hypr & H. hirta & H. contortus & E. plana & \\
\hline Cattle & 7.42 & 4.06 & 4.96 & ** \\
\hline Sheep & 4.76 & 2.50 & 3.54 & \\
\hline Tris & A. appendiculatus & A. semialata & T. leucothrix & \\
\hline Cattle & 11.25 & 8.58 & 7.62 & * \\
\hline Sheep & 7.97 & 8.00 & 5.57 & \\
\hline
\end{tabular}

of less-preferred species also occurring. The second stage occurred when about $60 \%$ of the tillers of the preferred species had been defoliated and was characterized by regrazing of these tillers coupled with increased utilisation of less-preferred species. The third and final stage commenced when $80-100 \%$ of tillers of the preferred and less-preferred species had been defoliated at least once and grazing of previously avoided species was finally initiated. This sequence of species selection was essentially the same for both cattle and sheep, although the preference shown for different grasses varied somewhat between the 2 animal species. Sheep were also more selective and tended to delay grazing avoided species until later in the grazing period than did cattle (Fig. 1).

These results corroborate the general sequence of species selection reported by Daines (1980) and Danckwerts et al. (1983), for cattle grazing Döhne sourveld and semi-arid grassveld, respectively. Similar results have also been reported by $O^{\prime}$ Reagain and Mentis (1989) for cattle on a secondary grassland community and by Stoltsz and Danckwerts (1990) for cattle and sheep grazing together on Döhne sourveld. A feature common to all studies, was that animals consistently selected previously defoliated tussocks of preferred species rather than graze the undefoliated, avoided species in the sward.

The overall consistency of these results suggests that this general sequence of species selection is of fairly wide applicability in rotational grazing systems having relatively short periods of occupation. However, the extent to which this sequence operates where periods of occupation are longer, is unclear. Possibly, where grazing periods are sufficiently long, and conditions suitable for rapid growth, preferred species may regrow sufficiently to allow animals to return to such regrowth before being forced to graze less-preferred species. Interestingly, animals at high stocking densities still select preferred species first, but are forced to consume avoided species sooner than under light stocking (Daines 1980; Stoltsz and Danckwerts 1990), simply because the availability of preferred plants is depleted more rapidly. Stocking density therefore appears to affect only the 'rate' at which the sequence proceeds and not the order of selection per se.

A basic prediction of optimal foraging theory is that as food availability declines, dietary breadth should be widened (Emlen 1966) with foods being added to the diet in the rank order of their
Table 6. Mean \% tiller length removed by cattle and sheep for different grass species at 4 sites in the Dōhne sourveld. Statistical comparisons are for cattle versus sheep at each site. (Site codes are as for Table 1).

\begin{tabular}{|c|c|c|c|c|}
\hline Site & & Species & & Cattle vs sheep \\
\hline \multicolumn{5}{|c|}{$\ldots-\ldots(\%)-\ldots \ldots$} \\
\hline Them & A. semialata & T. triandra & T. leucothrix & \\
\hline Cattle & 63.6 & 64.8 & 61.1 & ** \\
\hline Sheep & 64.0 & 69.2 & 72.1 & \\
\hline Erag & A. appendiculatus & T. triandra & E. plana & \\
\hline Cattle & 69.1 & 71.4 & 70.4 & ** \\
\hline Sheep & 79.9 & 80.3 & 77.8 & \\
\hline Hypr & H. hirta & H. contortus & E. plana & \\
\hline Cattle & 69.9 & 64.9 & 77.3 & ** \\
\hline Sheep & 73.8 & 81.5 & 81.6 & \\
\hline Tris & A. appendiculatus & A. semialata & T. leucothrix & \\
\hline Cattle & 64.0 & 52.1 & 56.6 & * \\
\hline Sheep & 73.2 & 61.9 & 71.2 & \\
\hline
\end{tabular}

utility to the animal (Pyke et al. 1977). Assuming that animals forage optimally and preference is a function of utility, then the observed sequence of selection was in broad agreement with this prediction. Both sheep and cattle only consumed less-preferred species to any marked degree later in the grazing period when herbage availability had been depleted. Once a new food has been included in the diet it should always be consumed when encountered (Krebs and McCleary 1984), i.e. an all-or-nothing response. However, while an obvious step-function was evident in some situations, e.g. E. plana at the eragrostis site (Fig. 2), in others the utilisation of less-preferred grasses was simply increased from low to high levels, indicating that these species were seldom totally excluded from the diet.

The decision to eat a lower-ranking food (species) should also depend upon the abundance of more-preferred foods and should be independent of its own abundance (Pyke et al. 1977). This occurred in the present study where the consumption of less-preferred species was strongly dependent upon the extent of defoliation and, therefore, the availability of more-preferred species. A threshold effect (Fig. 2) was evident at all sites with utilisation of less-preferred species being low or non-existent when ungrazed tufts of preferred species were readily available. Once the availability of such tufts had been depleted, utilisation of less-preferred species increased sharply.

The regrazing of tillers of preferred species when other, ungrazed species were available is unexpected. The major proportion of a tiller $(>60 \%)$ is removed in the first defoliation (O'Reagain; unpublished data) so regrazings are likely to yield very small bites which are also likely to be of relatively poor quality as regrazings often extend below the leaf collar (pers. obs.) into the tough, fibrous tiller bases. Although the more-preferred species may be of higher overall quality, it is difficult to accept that a second bite from a previously grazed tiller could be of a superior value to a fresh bite from an undefoliated, albeit slightly lower quality, species. This suggests that the regrazing of tillers is suboptimal. However, over longer time periods, where tiller regrowth is possible, the high quality of such regrowth may outweigh its small potential bite size, making the regrazing of preferred tillers an evolutionary stable strategy.

The sequence of species selection over the grazing period is of direct relevance to rangeland management. For example, non- 


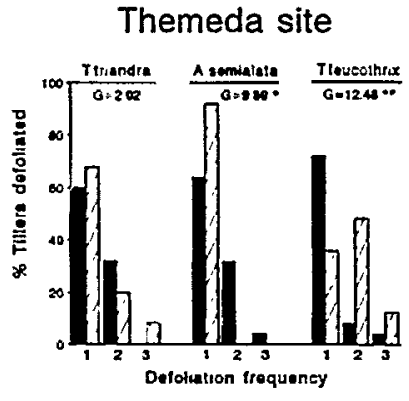

Eragrostis site

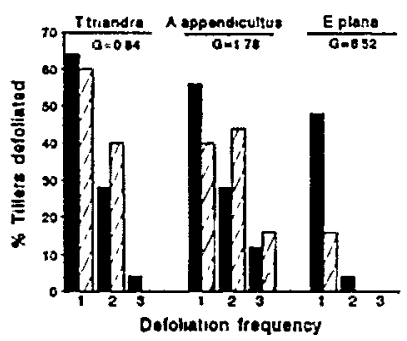

Tristachya site

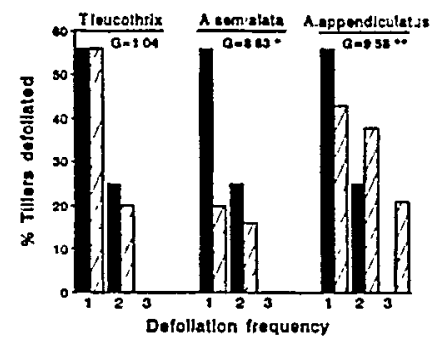

Hyparrhenia site

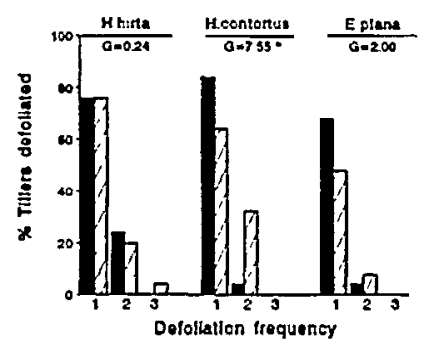

凹SHEEP D CATTLE

Fig. 3. Total percentage of tillers defoliated 1, 2, or 3 times over the grazing period under cattle and sheep grazing at 4 sites in the Döhne sourveld. $\mathrm{G}^{2}$-values refer to cattle-sheep comparisons for each grass species, * $(P \leq 0.05)$, ** $(P \leq 0.01)$.

selective (Acocks 1966) or high-utilization (Booysen 1969) grazing is based on the assumption that heavy stocking densities can be used to force animals to utilize avoided species in the sward. This allegedly decreases the relative abundance of such species as they are supposedly relatively intolerant of grazing (Acocks 1966; Booysen 1969; Edwards 1981). However, the results reported here, and in other studies (Daines 1980; Danckwerts et al. 1983; O'Reagain and Mentis 1989), suggest that the basic concept of non-selective grazing is flawed, and is in practice, largely unattainable. Furthermore, the damage resulting to preferred species in trying to achieve such an objective is likely to outweigh any potential benefit arising from the utilisation of the less desirable species in the sward.

A basic management recommendation for the Döhne sourveld is that animals should be removed from a paddock when $80-90 \%$ of the tufts of the preferred species have been grazed (Barnes 1989). However, the present results indicate that at this stage extensive regrazing of preferred species has already been initiated (Fig. 1), suggesting that this recommendation could possibly result in excessive utilisation of these species. It is therefore suggested that if a primary objective is to prevent the excessive defoliation of the preferred grasses, then animals be removed from a paddock when about $60-70 \%$ of these plants have been defoliated.

In general, the frequency of tiller defoliation was similar under cattle and sheep grazing. Although significant differences in defoliation frequency were apparent for certain species (Fig. 3), these were inconsistent, apparently reflecting differences in preference between the 2 animal species, i.e. both cattle and sheep tended to repeatedly defoliate preferred species. Accordingly, the hypothesis that sheep defoliate tillers more frequently than cattle during a grazing period is rejected. However, given the relatively small sample sizes used, the possibility of a Type II error cannot be discounted. More importantly, defoliation frequency was measured over a relatively short period ( 6 days), and thus did not consider defoliation of regrowth which would be of relatively greater significance to the plant. Consequently, the present results are inconclusive and further investigation using larger sample sizes and longer grazing periods is suggested.

The severity of tiller defoliation was, however, greater under sheep than under cattle grazing; sheep always grazed tillers at a lower height, removing a greater proportion of the tiller than did cattle (Tables 5 and 6). The hypothesis that the severity of tiller defoliation is greater under sheep than under cattle grazing is therefore accepted. The consistency of the above observation at all sites and across 7 grass species, some of which had a very low preference ranking for sheep, suggests that this finding is robust and likely of wide applicability.

Cattle and sheep tended to defoliate different species to different degrees, suggesting that their relative impacts on species composition in sourveld are likely to be different. Further, the impact of sheep on rangeland might be expected to be relatively more detrimental for 2 reasons. First, although the difference between the proportion of tiller removed by cattle and sheep appears relatively small $( \pm 10 \%)$, on an average of $4-6$ defoliations per season (Gammon and Roberts 1978a), the cumulative difference in tissue loss for an individual plant is likely to be significant. Second, sheep appear to concentrate on a narrower range of species, so that at equivalent stocking densities preferred species are likely to experience a greater intensity of defoliation than under cattle grazing. On this basis, the present study supports the general contention (O'Reagain and Turner 1992) that sheep have a greater potential to cause rangeland degradation than cattle. 


\section{Literature Cited}

Acocks, J.P.H. 1966. Non-selective grazing as a means of veld reclamation. Proc. Grassl. Soc. So. Afr. 1:33-39.

Acocks, J.P.H. 1988. Veld types of South Africa. Mem. Bot. Surv. So. Afr. 57.

Barnes, G.R. 1989. Management of veld types: sour grassveld, p. 149-155. In: J.E. Danckwerts and W.R. Teague W.R. (eds.), Veld management in the eastern Cape. Government Printer. Pretoria, So. Afr.

Booysen, P. de V. 1969. An analysis of the fundamentals of grazing management systems. Proc. Grassl. Soc. So. Afr. 4:84-91.

Caswell, H. 1989. Matrix population models. Sinauer Assoc., Sunderland, Mass.

Daines, T. 1980. The use of grazing patterns in the management of Döhne sourveld. Proc. Grassl. Soc. So. Afr. 15:185-188.

Danckwerts, J.E., A.J. Aucamp, and H.J. Barnard. 1983. Herbaceous species preference by cattle in the False Thomveld of the eastern Cape. Proc. Grassl. Soc. So. Afr. 18:89-94.

Edwards, P.J. 1981. Grazing managment. In: N.M. Tainton (ed.), Veld and pasture management in South Africa. Shuter and Shooter, Pietermaritzburg.

Emlen, J.M. 1966. The role of time and energy in food preference. Amer. Natur. 100:611-617.

Gammon, D.M., and B.R. Roberts. 1978a. Patterns of defoliation during continuous and rotational grazing of the Matopos sandveld of Rhodesia. 3. Frequency of defoliation. Rhod. J. Agr. Res. 16:147-164.

Gammon, D.M., and B.R. Roberts. 1978b. Patterns of defoliation during continuous and rotational grazing of the Matopos sandveld of Rhodesia. 2. Severity of defoliation. Rhod. J. Agr. Res. 16:133-146.

GENSTAT. 1984. GENSTAT 5 User's guide. Lawes Agr. Trust, United Kingdom.

Gibbs Russell, G.E., L. Watson, M. Koekemoer, L. Smook, N.P. Barber, H.M. Anderson, and M.J. Dalling. 1990. Grasses of southern Africa. Mem. Bot. Surv. So. Afr. 58. Nat. Bot. Gardens, So. Afr.

Gillen, R.L., F.T. McCollum, and J.E. Brummer. 1990. Tiller defoliation patterns under short duration grazing in tallgrass prairie. J. Range Manage. 43:95-99.

Hodgson, J. 1966. The frequency of defoliation of individual tillers in a set-stocked sward. J. Brit. Grassl. Soc. 21:258-263.
Hodgson, J., and J.H. Ollerenshaw. 1969. The frequency and severity of defoliation of individual tillers in set-stocked swards. J. Brit. Grassi. Soc. 24:226-234.

Hurlbert, S.H. 1981. Pseudoreplication and the design of ecological experiments. Ecol. Monogr. 54:187-211.

Krebs, J.R., and R.H. McCleary. 1984. Optimization in behavioral ecology, p. 91-121. In: J.R. Krebs and N.B. Davies (eds.). Behavioral ecology: an evolutionary approach. Blackwell, London.

Meissner, H.H. 1982. Classification of farm and game animals to predict carrying capacity. Farming in So. Afr. Pamphlet series. Beef Cattle C.3. Government Printer, Pretoria, So. Africa.

O'Reagain, P.J. 1992. Plant structure and the acceptability of different grasses to sheep. J. Range Manage. 46:232-236.

O'Reagain, P.J. 1994. The effect of sward structure and species composition on dietary quality and intake in cattle and sheep grazing the Dohne Sourveld. Ph.D. Thesis, Univ. Witwatersrand. Johannesburg, So. Africa.

O'Reagain, P.J. and M.T. Mentis. 1989. Sequence and process of species selection by cattle in relation to optimal foraging theory on an old land in the Natal Sour Sandveld. J. Grassl. Soc. So. Afr. 6:71-76.

O'Reagain, P.J., and J.R. Turner. 1992. An evaluation of the empirical basis for grazing management recommendations for rangeland in southern Africa. J. Grassl. Soc. So. Africa. 9:38-49.

Pagano, M., and Gauvreau K. 1993. Principles of biostatistics. Duxbury Press, Calif.

Pyke, G.H., H.R. Pulliam, and E.L. Charnov. 1977. Optimal foraging: a selective review of theory and tests. Quart. Rev. Biology 52:137-154.

SAS Institute. 1991. SAS/STAT User's guide, Release 6.03, 6th Ed. Cary, N.C.

Sokal, R.R., and F.J. Rohlf. 1981. Biometry. W.H. Freeman, N.Y.

Stoltsz, C.W., and J.E. Danckwerts. 1990. Grass species selection patterns on rotationally-grazed Döhne sourveld during autumn and early winter. J. Grassl. Soc. So. Africa. 7:92-96. 